\title{
Positionalities, Personal Epistemologies, and Instruction: An Analysis
}

\author{
Omer Avci \\ Correspondence: Omer Avci, Lifelong Learning and Adult Education Department, Istanbul Medeniyet University, \\ Turkey
}

Received: March 15, 2016 Accepted: March 21, 2016 Online Published: March 25, 2016

doi:10.11114/jets.v4i6.1462

URL: http://dx.doi.org/10.11114/jets.v4i6.1462

\begin{abstract}
Individuals' sense of who they are and what their positions are in relation to others is known to be their positionality. Positionalities influence individuals' conception of the world, thus their epistemologies. A few of the positionalities that exist, and included in this paper, are gender, spirituality, race/ethnicity, and social class. All these positionalities are socially constructed phenomena that affect individuals' personal epistemologies. Not only do the educators' positionalities and thus their epistemologies need to be examined, but also the influence of positionalities of learners on their epistemologies deserves to be studied. These positionalities could co-exist, thus, multiple positionalities could be affecting personal epistemologies. Certain situations require particular positionality to be more salient than others. Therefore, epistemologies tend to be situational.
\end{abstract}

Keywords: Epistemology, positionality, situational epistemology

\section{Introduction}

Epistemology is a branch of philosophy that deals with knowledge. Questions regarding the nature of knowledge such as what knowledge is, how it is created, how reliable or valid it is and how we could be sure about it, whose knowledge can be trusted and why are all the core questions that have concerned philosophers for a long time. Despite being primarily a branch of philosophy, and thus philosophers' realm of thought, there have been a growing number of fields interested in epistemology outside of philosophy. Education, particularly educational psychology, is one of these fields (Hofer, 2001). According to Hofer (2001), learners' conceptions of knowledge and knowing as part of the learning process have attracted researchers since the mid twentieth century.

What it takes for a learner to learn and the role of knowledge in this process has been the center of investigation. Scholars in the field of education are constantly seeking to find ways of making education worth their efforts, namely, reaching the educational objectives, which includes enhancing learning. The underlying mechanisms of human learning have been investigated from various approaches such as behaviorist one that considers learning to be a mere behavior change, cognitive approach that looks at learning as information processing and thus a more of a neuro-biological process, and constructivist approach that sees learners as the creators of knowledge, constructing knowledge rather than passive recipient and/or transferor of knowledge. Beside learners, teachers also have been focus of interest in educational and epistemological research. The epistemologies of teachers affect their teaching practices and decisions as educators (Hofer, 2001; Nespor, 1987; Stuart \& Thurlow, 2000).

Epistemological research in education focuses on the relationship between epistemology and learning, cognition, academic success and how it fosters educational development (Baxter Magolda, 1992; Hofer, 2001; Perry, 1970). However, there is not much clarity in the literature regarding the relationship between epistemology and educational attainment, and especially between epistemology and teaching strategies and methods and epistemology (Hofer, 2001). suggests a working model of relationship between epistemology and teaching and learning. According to her, teachers' epistemological beliefs influence their instructional strategy, classroom tasks and practices selection, which, then, affect students' epistemological beliefs. Students' epistemological beliefs not only affect their motivation but also their beliefs about learning and education, which both influence their study and learning strategy selection, which consequently affect their learning (Hofer, 2001).

Despite the growing interest in the relationship between epistemology of individuals and education and instructional attainment, the construct of epistemology is not universally unequivocal. Pajares (1992, p.307) very aptly calls it a "messy construct" and attempts to clarify the construct of epistemological beliefs. In the literature, the construct that deals with epistemology and instruction and learning are termed as epistemological beliefs (Jehng et al., 1993, Kardash 
and Howell, 2000; Kardash \& Scholes, 1996; Schommer, 1990, 1998), reflective judgement (King and Kitchener1994; 2001) ways of knowing (Belenky et al., 1986) epistemological reflection (Baxter Magolda, 1992; 1999; 2002), epistemological theories (Hofer \& Pintrich, 1997) epistemic resources (Hammer \& Elby, 2002), personal epistemology (Hofer, 2001), epistemological thinking (Kuhn \& Weinstock, 2001), standpoint epistemologies (Harding, 1993), and positionalities (Bondi, 1997; Takacs, 2002). Though, the last term is usually suggested to be connected to epistemology (Takacs, 2002; 2003), positionality is considered to influence and shape our epistemologies; and thus, it is a means to understanding and forming epistemology.

Even though epistemological studies seem to have focused on formal instruction and instructional settings, it is not limited to school learning; rather, it is a very significant element of lifelong learning, which includes individuals' conceptual positions in case of various competing knowledge claims and evaluating novice knowledge and thus make important decisions in life (Hofer, 2001; King \& Kitchener, 1994; Kuhn, 1991).

Instructional implications of epistemology that have been put forward, though not very thoroughly, have yet to clarify the dubious mechanism of epistemological thoughts and the teaching and learning processes. To add to the existing notions, positionalities of individuals may also be affecting epistemologies (Takacs, 2002; 2003). Maher and Tetreault (2001) define positionality as "the idea of positionality, in which people are defined not in terms of fixed identities, but their location within shifting networks of relationships, which can be analyzed and changed." (p. 164). In other words, the individuals' sense of who they are and what their positions are in relation to others influence their conception of the world. The positionality of people is a strong determinant of the power they have and the things that they can get access to. The positions that currently exist are constructed by society, and its culture, norms, and values. As members of our communities, we are doomed to wear the dresses of race/ethnicity, class, gender, and spirituality, which then become our identities. Previously, most adult educators who were interested in the notion of development in adulthood focused on the individual (Merriam, Caffarella, \& Baumgartner, 2007).

Our perceptions of race/ethnicity, gender, spirituality, and social class are heavily influenced by the society in which we live. What we know, think, feel, and believe about race, gender, spirituality, and social class are usually determined and constructed by the education we receive, the interactions we have, and other aspects of our social lives. In this sense, people from different cultures and societies may have different perceptions - race and gender as their perceptions are constructed by the society and culture they belong to.

The purpose of this paper is to scrutinize the literature to find out how positionalities of learners and educators influence their epistemologies. I am going to examine gender, spirituality, race, and social class. Most of the time the positionalities are interwoven with another and it is difficult to decide which positionality is the dominant one. After examining the literature, I am going to make suggestions for educators to use in their educational practices.

\section{Gender and Epistemology}

Do women learn differently than do men? Are there any uniquely female learning characteristics? These are the fundamental questions underlying gendered epistemologies. Seeking answers to these questions can help us understand the mechanisms underlying the gender epistemology relationship. In addition, studying gender differences could help us figure out the existing gendered inequalities, improve academic and cognitive performances, and better understand how students learn (Programme for International Student Assessment, 2009). When we examine the studies related to gender, we could categorize them in three perspectives: Psychological, biological, and sociocultural.

\subsection{Psychological Perspectives}

Hayes (2001) argues that in some parts of the literature, women are portrayed as feeling-oriented, and therefore they like to share feelings, while men are portrayed as more fact and problem-oriented in nature. Relationship and emotion are two orientations of women, which also influence the way they learn. Women are also more attentive to social contexts. A series of studies focusing on the cognitive abilities of male and female brains reveal that women have a tendency to learn in terms of the context rather than learn independently of it (as men are more prone to do). Though this has not been universally accepted. The fact that women are usually involved more in relationships than men and they are more concerned about separation-related issues very much supports the findings.

\subsection{Biological Perspectives}

Most theories that try to explain how women learn are based on psychology (Halpern, 2012; Hayes, 2001). Even though there is more research needed, recent studies of brain function show that women's brains are active in certain cognitive tasks, compared to those of men's (Hayes, 2001). Females have a slight superiority in verbal reasoning, vocabulary size, and verbal fluency over males (Halpern, 2012; Sherman, 1978). As for visuospatial abilities, differences in favor of males are spatial perception, mental rotation, spatiotemporal ability, and generation and maintenance of visual images. Females, on the other hand, tend to be better at spatial visualization (Halpern, 2012). 
Women have different sensory skills than do men. According to Notman and Nadelson (1990), the male and female brains differ from each other. Women gain knowledge and deal with others through verbal communication, which is a mode that they favor. As baby girls are more sensitive to sounds, women are more selective to tones than are males. Females have more skin sensitivity than do males, and girls are better at fine motor skills. According to Halpern (2012), tasks involving mental representations are performed better by males, while females' performance of retrieval of verbal information from memory is stronger. The effect of sex hormones on learning and memory processes has also been documented (Cahill, 2006). Another gender difference in sensation is that after the age of 40, women retain higher sensitivity than men in tasting because of sex hormones that influence sensitivity to taste and taste preference. In addition, studies indicate that there are sex differences in smelling sensitivity. Hearing is another sensation that females have greater sensitivity than males because as we age, the above differences get more pronounced (Notman \& Nadelson, 1990).

The society and the environment in which an individual lives, have a great effect on the development and maturation of the brain (Halpern, 2012). Both hemispheres of the brain start to grow and become specialized at different tasks at their peak when the sex hormones are produced. There are differences between male and female brains, some of which are "the length of nerve cell receptors, pathways the nerves follow, and location of control centers form language, emotion, and spatial skills" (Hill, 2001, p.74). Female brains are stimulated by emotions more than do male brains. There is no evidence, however, that male brains being bigger than the female brains have anything to do with intelligence. Female brains maintain their flexibility and are more resistant to degeneration as we age. Hill (2001) adds that "the most flexible parts of the brain involve higher functions evolved in the cerebral cortex such as thought, memory, and learning" (p.75).

\subsection{Sociocultural Perspectives}

As noted above, the explanations so far, have been on how women's learn, and-how different they are from males, and how they are more heavily dependent on psychological and biological perspectives. However, most conceptions of gendered behaviors and characteristics do not result from merely biological and psychological theories, rather these conceptions are derived from cultural and social beliefs. Crawford, Chaffin, and Fitton (1995) define gender as "what culture makes out of the 'raw material' of biological sex" (p. 341). Merriam, Caffarella, and Baumgartner (2007) state that sociocultural points of view approach the effects of gender on development of individuals differently from those who look at the issue from a more psychological point of view. The context and environment in which individual development of women takes place are often ignored in the psychological tradition, despite the fact that context and environment are the necessary components that allow researchers to understand such development. Individuals are taught gender roles and gender ways in the society they live in, but these are often not questioned or critically analyzed. In the U.S., it is the male experience that constitutes the norm. Despite the biological differences of men and women, their behaviors, talents, or abilities are determined by the society and culture in which they socialize (Halpern, 2012; Notman \& Nadelson, 1990). In addition, every society is composed of hidden assumptions about how the members of that society should behave, look, think, and feel (Renzetti \& Curran, 1989). "These hidden assumptions are embedded in cultural discourses, social institutions, and individual psyches, so that generation after generation, specific patterns of thought, behavior, and so on are invisibly, but systematically reproduced" ( Renzetti \& Curran, 1989, p. 65). Bem (1993) calls these hidden assumptions lenses, through which members of the society acquire cultural values. In her enculturated gender lens theory, Bem tries to explain how individuals acquire their gender identities. According to Bem (1993), there are three lenses in the United States and in most Western societies: gender polarization, androcentrism, and biological essentialism. From very early ages, these lenses (hidden assumptions) are acquired and through these lenses gender appropriate behaviors, feelings, looks, and discourses are acquired (Renzetti \& Curran, 1989).

Even though most previous studies on learning heavily focused on male samples, more and more researchers become more interested in hearing the voices of women in order to shed light on how women learn. In order to find out whether the existing male-dominated conceptions of the ways of learning were applicable to everyone, the seminal study of Belenky, Clinchy, Goldberger, and Tarule provides a great resource for gender differences in learning (Merriam et al., 2007). The researchers interviewed 135 women, who had very diverse social and ethnic backgrounds and also from diverse academic institutions and parenting classes. The authors came up with five major categories of women's ways of knowing: silence, received knowledge, subjective knowledge, procedural knowledge, and constructed knowledge (Belenky et al., 1986, p. 15).

Merriam et al. (2007) state these categories are not universal or unchangeable. When examined carefully one will notice that the order of the categories goes from simple to complex. It starts with women being quiet and recipient and move to the level of owning and creating knowledge. 
Hurtado (1996) examines the five mechanisms that are important to creating and gaining knowledge for minority women. These mechanisms are anger, silence, withdrawal, shifting consciousness, and multiple tongues. Anger is one of the survival mechanisms that seem to be necessary for the women of color. Even though anger can impede access to knowledge, when used effectively, it facilitates the gaining of knowledge. From an early age, women of color learn that knowledge is not fixed and truth is relative and they are both determined by the political and social context in which they exist. The racist and sexist environment that usually exist in society create anger in women of color, and which then can be used productively to gain knowledge. Often the anger leads to solidarity within the particular race or ethnic group. However, the anger felt may lead to exaggerated solidarity that impedes the judgments of women of color, which make them vulnerable to abuse of the men in their own race or ethnic group.

Controlled silence can become a powerful mechanism especially for women of color. Silence is used to camouflage them and provide the means for safe observation, which is shared in their communities. Outspokenness is used to balance silence, which then serves as a means to acquire and practice knowledge (Hurtado, 1996).

Many women of color are destined to withdraw to their networks of genders because of the social life situations (Hurtado, 1996). She states that "The distance from men also allows many women of color to develop their own sense of authority" (p. 383). The harshness of social and economic life situations force women of color to get into the public sphere in order to survive.

Another important mechanism is the shifting consciousness, which is defined as the "ability of many women of color to shift from one group's perception of social reality to another, and at times, to be able simultaneously to perceive multiple social realities without losing their sense of self-coherence" (Hurtado, 1996, p.384). Being able to shift consciousness enabled the women of color to connect different sides of arguments, which is the fifth mechanism having multiple tongues. Women of color have gained the skill to "talk to different audiences without losing a sense of coherence" (Hurtado, 1996, p.385).

\section{Spirituality and Knowledge}

While adult educators are seeking the best theories and practices for social transformation and are often teaching across the borders of race, ethnicity, gender, class, and sexual orientation, they are faced with the reality of helping the adult learners understand what is beyond these borders. Even though the above mentioned borders are widely discussed in the field of adult education, one very central aspect of life usually remains unnoticed or discussed among the scholars: spirituality (Tolliver \& Tisdell, 2002).

Spirituality and religion are connected, yet they are not the same. Spirituality is the conscious effort of realizing the life force that exists in everything including the learning environment, making meaning, and experiences, which lead to wholeness and interconnectedness in life. Spirituality involves symbolic processes through which individuals construct knowledge. Usually these symbolic processes, which include images, symbols, and music, are not noticed by the individuals. Spirituality helps people become aware of their selves. Spirituality is often embedded in culture (Tolliver \& Tisdell, 2002). Another distinction between religion and spirituality is that "religion is an organized community of faith that has written codes of regulatory behavior, whereas, spirituality is more about one's personal belief and experience of a higher power or higher purpose" (Tisdell, p. 2).

Tisdell (1999) states that spiritual development is often approached from a psychological perspective. Fowler (1981), who uses the word faith instead of spirituality, criticizes the moral and cognitive development theories of Kohlberg and Piaget because of their limited understanding and negligence of symbolic processes. The six stages of faith development are intuitive-projective faith, mythical-literal faith, synthetic-conventional faith, individuative-reflective faith, conjunctive faith, and universalizing faith. Individuals go through the first two stages (intuitive-projective faith and mythical-literal faith) in their childhoods; therefore most adults are in the remaining stages or go through those stages. Since the world of the individual expands beyond family, other significant influences come into play, which means that the individual is not independent enough and cannot make judgments by him/herself, he/she needs the perspective of others, and which is why this is a conformist stage. In the fourth stage is the transition from synthetic-conventional faith to individuative-reflective faith stage, which requires the individual to take the responsibility for his/her faith. Conjunctive faith is the stage when the individual integrates the self and the outlook. It is not often that people reaches the last stage of universalizing faith, in which the individual is ready to embrace all beings.

The stage development theories, including Fowler's, are also subject to criticism. Tisdell (1999) notes that the hierarchical natures of these theories emphasize autonomy and ignore the importance of connection and relationships. They tend to fit better for men rather than for women. Another point that Fowler (1981) fails to make is that all forms of knowing that are present in the six stages of spiritual development are not devoid of the influences of the cultural and social backgrounds of individuals. 
Tisdell (1999) suggests that spirituality is connected to the meaning that adults make throughout their lives. That meaning helps adults fight for social transformation. Another suggestion is that adult educators should be aware of the fact that adults bring their spirituality into the learning environment, and which is often particularly true of women. People construct meaning through the images and symbols that originate from the spiritual dimension of the adult learner. The images and symbols cannot and should not be stripped off their social and cultural contexts. Failing to do so results in failing to comprehend the histories behind the learners and to connect the history to the present which then leads to the future. Failing to do this will maintain the status quo and the existing white, middle-class, Judeo-Christian way of knowing. Tisdell (1999) reminds us that Paulo Freire was a spiritual educator, and bell hooks also felt stronger because of her spirituality in her fight for a just world.

In attempting to understand how spirituality affects the motivations and practices of female adult educators from diverse sociocultural backgrounds, Tisdell (2000) reveals the findings of her qualitative study. There are five themes that can be detected in the spiritual experiences of female adult educators. The first theme is "spiral process of moving beyond and remembering" (Tisdell, 2000, p.7). Individuals first question their childhood religious understandings, which result in moving away from religion because of the institutionalized religion's hypocrisy, sexism, heterosexism, lack of personal or cultural support, or general irrelevance in relation to liberation politics" (Tisdell, 2000, p. 7). After moving away from religion, in adulthood, many people remember the symbols of faith from their childhoods and the meaning behind those symbols. When the individuals have a complete sense of their core values, they start to reframe their faith. The participants of the study re ported that defining spirituality was not an easy task. However, another emerging theme from the study shows that adult educators who participated in Tisdell's study have experienced life force and connectedness and wholeness through spirituality. The third theme emerging from the study is the pivotal experience of a perceived higher power that facilitates the healing process. In some part of their lives, most of the individuals experienced the presence of a higher power, which helped them solve their problems. Tisdell (2000) notes that almost all participants of the study expressed spiritual experiences which facilitated the development of an authentic identity. Spirituality cannot be regarded seperately from the development of their identities. While spirituality contributed to an individual's identity development, it also helped him/her accept the different identities of other people. The fifth theme that emerged from the study was that participants of the study expressed that their struggle for social change is fueled by their spiritualities. Spirituality requires "a way of life requiring inner reflection and action for social change" (Tisdell, 2000, p. 13).

Tisdell (2000) suggests that social transformation cannot be achieved through mere rational processes. One implication for adult educators is that adults bring their whole selves into the learning environment, which includes their spirituality. This does not mean that they should teach spirituality, rather that they should recognize its existence, and how it can foster learning which then leads to social transformation. Spirituality is often connected to the knowledge created through images and symbols, which often reveal themselves in the forms of art, music, drama, and dance. Another important reminder is that spirituality is not the complete opposite of rationality. Rationality is one of the components of spiritual development.

\section{Race/Ethnicity and Personal Epistemologies}

As stated earlier, race is one the positionalities that is socially constructed. One example of the construction of race is William Cross's theory of racial identity development, or nigrescence theory (Vandiver, Cross, Worrell, and Fhagen-Smith, 2002). (Tatum, 1997), Nigrescence theory tries to explain how African Americans get to acquire their racial identity. According to this theory, the young black person goes through five stages in his/her life. Before adolescence the person is at the pre-encounter stage, at which stage $s /$ he is not aware of the fact that his/her culture is different from the dominant (white) culture. The individual accepts the norms and values of the white culture. As s/he grows up, s/he encounters events that affect her/him adversely. These events make the individual realize that s/he is different from members of the dominant race. The next stage is that of emersion/immersion, at which the individual seeks support from his/her race peers. At this stage, the individual also tries to learn more about her/his own culture/ race, expresses and surrounds her/himself with racial symbols (listens to music of his/her race, wears particular clothes that is worn by his/her particular race group). The fourth stage is the internalization stage. However, not every person can go beyond the third stage (immersion) throughout her/his life. In the internalization stage, the person feels comfortable about his/her race. The last stage, which is very similar to the internalization stage, is internalization-commitment. At this stage the individual is confident of and comfortable with his/her racial identity and is ready to contribute to the welfare of his/her race.

After stating that race is socially constructed, Johnson-Bailey and Cervero (2000) add that the race exist in the forms of social power and privilege, and it also acts as a determinant of how the society functions (Johnson-Bailey \& Cervero, 2000). There are three major categories of perspectives on race in adult education: color-blind perspective, multicultural perspective, and social justice perspective (Johnson-Bailey \& Cervero, 2000). Color-blind perspective tends to omit and 
ignore the presence of race in literature, research, and praxis. Knowles's (1980) assumption that in a classroom the adult learners would be willing to share their ideas is based on middle class, white, Christian (Protestant) values (Johnson-Bailey \& Cervero, 2000). What if there were other groups of adult learners who value communalism or collectivism more than individualism and as a result of which they might not be willing to share their personal opinions. Certain cultures, such as Hispanics, African Americans, and Native Americans, put more emphasis on group and community values (Johnson-Bailey \& Cervero, 2000). Even though the color-blind perspective seems to be eradicating racial discrimination, but instead of creating a colorless learning and development environment, it serves to dictate the dominant culture's values, its practices in adult learning and development.

The multicultural perspective advocates that the values and beliefs of other cultures are needed to be taught beside those of the dominant culture (Johnson-Bailey \& Cervero, 2000). The social justice perspective treats power and privilege as central issues. The main mission of adult educators is to democratize citizenry and provide opportunities for the adult learners to correct the wrongs (inequality, injustice) of the society through education (Johnson-Bailey \& Cervero, 2000). In this perspective privilege is seen as a means to be heard, but at the same time it silences those of others. Race and class can serve as privileges for some adults, while they serve as barriers for others. Viewing societal power relationships in terms of race will help us realize the different groups of races, who are oppressed and ignored.

\section{Social Class and Personal Epistemologies}

The difference in child-rearing practices of working-class and middle-class families has been an issue of debate among researchers. Individuals' societal habitats help shape their daily lives through language and time usage and kin ties (Lareau, 2011). According to Chin and Phillips (2004), the differences between the above mentioned child-rearing practices of families of different social strata emerges from either parenting differences in values and expectations or the unequal resources that the families from differing strata's have access to. One of the studies that theorize families' child-rearing practices emerge from their differing values and expectations suggests that the relationship between social class and socialization reveals that there are consistent differences by social class in the values people hold (Jones, Gallagher, \& McFalls, 1999). "People in higher social classes are more likely to value self-direction, whereas working-class people tend to value conformity to external authority" (Jones et al., 1999, p.141). The children of working-class families are taught (by their parents) to be neat, good student, honest, and obedient. On the other hand, middle-class children are taught (by their parents) to be responsible and self-directed (Jones et al., 1999). When these children of different social classes become adults, they tend do follow the way they were taught and raised. Working-class adults value honesty and they are more obedient to prescribed rules. On the other hand, middle-class adults tend to emphasize development of their own internal standards and tend to be more self-directed.

Learners/students are not the only ones prone to reflecting the values of their social class. Tisdell, Hanley, and Taylor (2000) examine their positionalities and their effects on their teaching practices as adult educators. Taylor, who is from middle-class prefer to speak from the text instead of speaking from personal experience. He tends to be more rational and let logic guide them. Tisdell, who is a white female educator from middle-class, values relationships and she does not mind sharing their personal experiences in learning environments. Tisdell states that she includes diverse voices in her curriculum embedded in stories, interacts, songs, and discourses. She also admits that while doing so she is aware of the fact that she is white. Hanley states that she has to deal with her rage, which is a common issue for people of color.

\section{Discussion and Conclusion}

\subsection{Situation and Multipositionalities: Situational Epistemologies}

In the introduction section of this paper, the possibility of a person having multiple positionalities is mentioned. The co-existence of gender, spirituality, race/ethnicity, and social class should also be taken into account when dealing with personal epistemologies. So far, individual positionalities and their probable impact on epistemologies have been examined. However, real life situations are far more complex and complicated than having one positionality and thus affecting epistemology. Various combinations of aforementioned positionalities and epistemologies are worth scrutinizing. In the case of an individual, who is non-white, female, Muslim, and from a middle class background, what is the determining positionality for this particular individual's personal epistemologies? What determines an individual's positionality (or positionalities) among others to be salient? In other words, what are the sources of individual's epistemic dependence?

Since, the core argument in this study is that individual's innate cognitive abilities are not sufficient enough to explain personal epistemologies, the situations in which knowledge is acquired (or processed) could carry answers to the salience of certain positionalities. In situations where gendered perspectives are used or required, gender becomes more salient than other positionalities. A religious person, for example, facing any knowledge that contradicts with his/her faith could approach it suspiciously causing him/her to reject that knowledge. However, it is not always that clear whether, for example, gender or spirituality of the individual causes the person to reject or construct particular 
knowledge. Is one of the positionality more salient than the other? Or are they equally salient? Or are there other contributing positionalities to the construction of that particular knowledge? Situation might require multiple positionalities to go along construction of knowledge.

Figure 1 depicts various possible combinations of positionalities pertaining to epistemologies. These positionalities could be clustered as single, double, triple, and quadruple. Single positionality pertains to one of the following positionalities: gender (S1), social class (S2), ethnicity (S3), and spirituality (S4) are single positionalities that may affect personal epistemologies. These are situations where single positionality is the only salient and pertinent one to making sense of the world. Dual positionalities refer to situations in which two of the above mentioned positionalities together affect epistemologies. There are six possible dual positionality combinations. The intersections of gender and social class (D1), social class and ethnicity (D2), ethnicity and spirituality (D3), spirituality and gender (D4), social class and spirituality (D5), and gender and ethnicity (D6) generate the dual positionalities that influence personal epistemologies. The influence of triple positionalities on personal epistemologies is at the intersection of the three of the positionalities discussed here: The intersection of gender, social class, and spirituality (T1) indicates the influence of these three positionalities on personal epistemologies. T2 is the intersection of gender, social class, and ethnicity, all of which affect personal epistemologies. T3 refers to the intersection of social class, ethnicity, and spirituality, which may also influence personal epistemologies. The intersection of ethnicity, spirituality, and gender (T4) refers to the last possible triple combination of positionalities which maybe affecting personal epistemologies. All four of the positionalities together could influence personal epistemologies. In the figure, the intersection of this possible quadruple combination is marked as $\mathrm{Q}$.

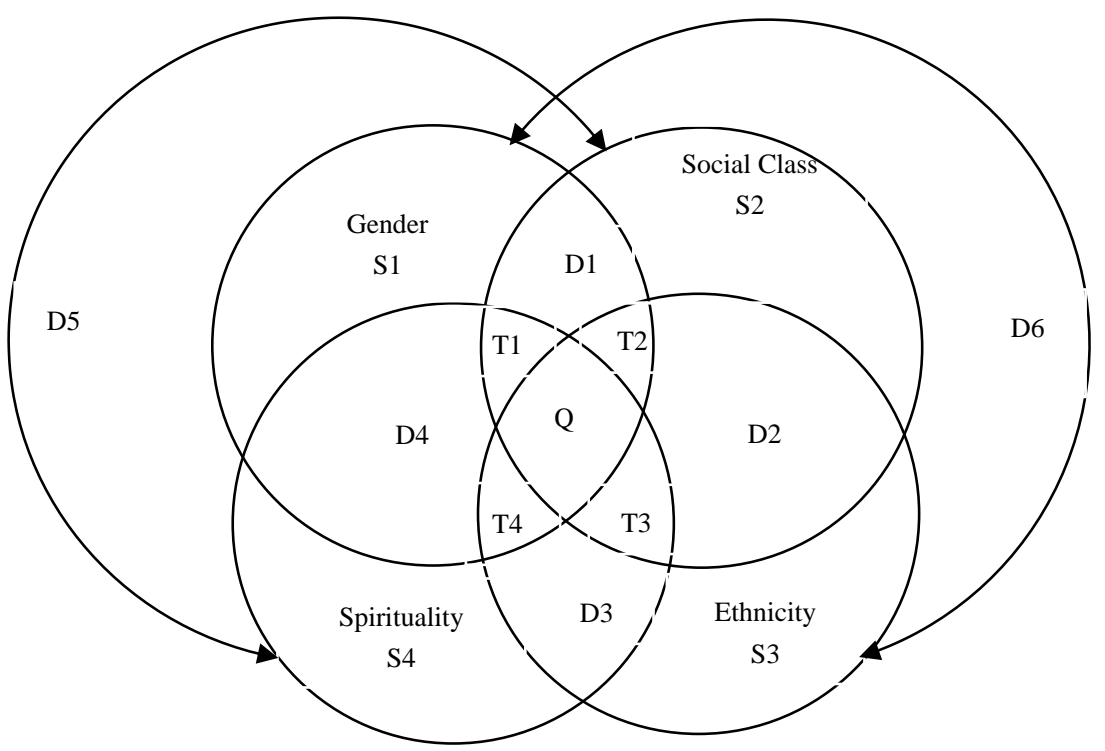

Figure 1. Positionalities pertaining to personal epistemologies

Determining various positionalities and their combinations is the first step to a more challenging task: Figuring out when and why certain positionality/positionalities become salient. It is clear that the nature and situation of knowledge in hand has a lot to do in the salience of the above mentioned positionalities. Future research could empirically explain the relationship between the salience of positionalities and the nature and situation of knowledge.

\subsection{Suggestions for Instruction}

Biological differences between males and females can facilitate adult learning settings. Since women have better sensory abilities of tactile, olfactory, auditory, and tasting, these sensory abilities can be incorporated in learning process, which help female learners retain information better. Presenting the learning material in context and involving emotions will increase retention.

The five major ways of female knowing provides adult educators a great framework in designing their curricula. However, the primary task of the adult educator is to determine which of the five categories of knowing the individual fits in. It is not easy to determine prior to the beginning of education, however, flexible curricula that can be later modified in order to cater the needs of the learners. Having various instructional strategies and tasks that can address to female students at different levels can increase learning.

The five mechanisms can be channeled through instructional strategies that will enhance learning. For example, women 
of color have multiple tongues, which allows them look at things from different perspectives. These multiple tongues can enrich the content of the course. The educator can design collaborative activities through which women of color provide different perspectives and help other learners gain different knowledge.

Spirituality can facilitate transformational and emancipatory learning. Spiritual people believe in the healing power of a higher power and it can serve as a motivator for social change. Because spirituality is often related to symbols and images adult educators can use songs, art works, dances etc. that have spiritual symbols in order to get the attention of the learners and provide stimuli.

As for class and race/ethnicity, educators can use how these two notions are socially constructed and used to maintain the status quo. Adult educators should examine the curricula that they use in order to avoid instructions that support the dominant white cultural values. Narratives can serve to channel the anger felt by minority learners.

Being aware of the socially constructed and taken for granted positionalities of gender, spirituality, race/ethnicity, and social class will promote learning in education. For a just, equal, and democratic society that the value of human being is recognized is possible if we embrace and see our differences as sources. Recognizing the individual positionalities and using them to promote learning is the starting point of a better future.

As for classroom instruction, educators' awareness of not only their positionalities, situations, and how they affect their instruction, but also their students' epistemologies and the situations that require certain positionalities would help they employ instructional strategies that would foster learning. Instructors could also help their students become aware of their positionalities and personal epistemologies, which would help determine study strategies and become better learners.

\section{References}

Baxter, M. M. (2002). Epistemological reflection: The evolution of epistemological assumptions from age 18 to 30. In Hofer, B. K., and Pintrich, P. R. (eds.), Personal epistemology: The psychology of beliefs about knowledge and knowing. Mahwah, NJ: Lawrence Erlbaum Associates, Inc.

Baxter, M. M. B. (1992). Knowing and reasoning in college: Gender-related patterns instudents' intellectual development, San Francisco: Jossey Bass.

Baxter, M. M. B. (1999). The evolution of epistemology: Refining contextual knowledge at twentysomething. Journal of College Student Development, 40(4), 333-344.

Belenky, M. F., Clinchy, B. M., Goldberger, N. R., \& Tarule, J. M. (1986). Women's ways of knowing: The development of self, voice and mind. New York: Basic Books.

Bem, S. L. (1993). Dismantling gender polarization and compulsary heterosexuality: Should we turn the volume down or up? The Journal of Sex Research, 32(4), 329-334. http://dx.doi.org/10.1080/00224499509551806

Bondi, L. (1997). In whose words? On gender identities, knowledge and writing practices. Transactions of the Institute of British Geographers, 22(3), 245-258.

Cahill, L. ( 2006 ). Why sex matters for neuroscience. Nature Reviews Neuroscience, 7, 477-484. http://dx.doi.org/10.1038/nrn1909

Chin, T., \& Phillips, M. (2004). Social reproduction and child-rearing practices: Social class, children's agency, and the summer activity gap. Sociology of Education, 77(3), 185-210. http://dx.doi.org/10.1177/003804070407700301

Crawford , M., Chaffin, R., \& Fitton, L. (1995). Cognition in social context . Learning and Individual Differences, 7, 341-362 . http://dx.doi.org/10.1016/1041-6080(95)90006-3

Fowler, J. W. (1981). Stages of faith: The psychology of human development and the quest for meaning. New York: HarperCollins.

Halpern, D. F. (2012). Gender differences in cognitive abilities. New York: Taylor \& Francis.

Hammer, D., \& Elby, A. (2002). On the form of a personal epistemology. In Hofer, B. K., and Pintrich, P. R. (eds.), Personal Epistemology: The Psychology of Beliefs About Knowledge and Knowing. Mahwah, NJ: Lawrence Erlbaum Associates, Inc.

Harding, S. (1993). Rethinking standpoint epistemology: What is “strong objectivity"? In L. Alcoff \& E. Potter (Eds.), Feminist epistemologies (pp. 49-82). New York: Routledge.

Hayes, E. R. (2001). A new look at women's learning. In S. B. Merriam (Ed.), The new update on adult learning theory (pp. 35-42). San Francisco: Josey-Bass. http://dx.doi.org/10.1002/ace.6Hill, L. H. (2001). The brain and consciousness: sources of information for understanding adult learning. In S. B. Merriam (Ed.), The new update on 
adult learning theory (pp. 73-81). San Francisco: Josey-Bass. http://dx.doi.org/10.1002/ace.10

Hofer, B. K. (2001). Personal epistemology research: Implications for learning and teaching. Journal of Educational Psychology Review, 13(4), 353-383. http://dx.doi.org/10.1023/A:1011965830686

Hofer, B. K., \& Pintrich, P. R. (1997). The development of epistemological theories: Beliefs about knowledge and knowing and their relation to learning. Review of Educational Research, 67(1), 88-140. http://dx.doi.org/10.3102/00346543067001088

Hurtado, A. (1996). Strategic suspensions: feminists of color theorize the production of knowledge. In N. Goldberger, J. Tarule, B. Clinchy, \& M. Belenky (Eds.), Knowledge, difference, and power: essays inspired by women's ways of knowing (pp. 372-392). New York: Basic Books.

Jehng, J. C. J., Johnson, S. D., \& Anderson, R. C. (1993). Schooling and students' epistemological beliefs about learning. Contemporary Educational Psychology, 18, 23-25. http://dx.doi.org/10.1006/ceps.1993.1004

Johnson-Bailey, J., \& Cervero, R. M. (2000). The invisible Politics of Race in Adult Education. In A. L. Wilson, \& E. R. Hayes (Eds.), Handbook of Adult and Continuing Education. (pp. 147-160). San Francisco: Josey-Bass. Kardash, C. M., \& Howell, K. L. (2000). Effects of epistemological beliefs and topic-specific beliefs on undergraduates' cognitive and strategic processing of dual-positional text. Journal of Educational Psychology, 92, 524-535. http://dx.doi.org/10.1037/0022-0663.92.3.524

Kardash, C. M., \& Scholes, R. J. (1996). Effects of preexisting beliefs, epistemological beliefs, and need for cognition on interpretation of controversial issues. Journal of Educational Psychology, 88(2), 260-271. http://dx.doi.org/10.1037/0022-0663.88.2.260

King, P. M., \& Kitchener, K. S. (1994). Developing reflective judgment: Understanding and promoting intellectual growth and critical thinking in adolescents and adults, Jossey-Bass, San Francisco.

King, P. M., \& Kitchener, K. S. (2002). The reflective judgment model: Twenty years of research on epistemic cognition. In Hofer, B. K., and Pintrich, P. R. (eds.), Personal Epistemology: The Psychology of Beliefs About Knowledge and Knowing, Erlbaum, Mahwah, NJ.

Kuhn, D. (1991). The skills of argument. Cambridge, England: Cambridge University Press. http://dx.doi.org/10.1017/CBO9780511571350

Kuhn, D., \& Weinstock, M. (2002).What is epistemological thinking and why does it matter? In Hofer, B. K., and Pintrich, P. R. (eds.), Personal Epistemology: The Psychology of Beliefs About Knowledge and Knowing, Erlbaum, Mahwah, NJ.

Lareau, A. (2011) Unequal childhoods : class, race, and family life. Los Angeles: University of California Press.

Maher, F. A., \& Tetreault, M. K. T. (2001). The feminist classroom: Dynamics of gender, race, and privilege. Lanham, MD: Rowman and Littlefield Publishers.

Merriam, S. B., Caffarella, R. S., \& Baumgartner, L. M. (2007). Learning in adulthood: A comprehensive guide. San Francisco: Josey-Bass.

Nespor, J. (1987). The role of beliefs in the practice of teaching. Journal of Curriculum Studies, 19(4), 317-328. http://dx.doi.org/10.1080/0022027870190403

Notman M. \& Nadelson C.C. (1991). Women and men: New perspectives on gender differences. Washington, DC: American Psychiatric Press.

Pajares, F. (1992). Teachers' beliefs and educational research: Cleaning up a messy construct. Review of Educational Research, 62(3), 307-332. http://dx.doi.org/10.3102/00346543062003307

Perry, W. G. (1970). Forms of intellectual and ethical development in the college years: A scheme. New York: Holt, Rinehart and Winston.

Programme for International Student Assessment ( 2009 ). Equally prepared for life? How 15-year-old boys and girls perform in school. Retrieved from http://www.oecd.org/dataoecd/59/50/42843625.pdf

Renzetti, C. M., \& Curran, D. J. (1989). Women, men, and society: The sociology of gender. Boston : Allyn and Bacon.

Schommer, M. (1990). Effects of beliefs about the nature of knowledge on comprehension. Journal of Educational Psychology, 82, 498-504. http://dx.doi.org/10.1037/0022-0663.82.3.498

Schommer, M. (1998). The influence of age and education on epistemological beliefs. British Journal of Educational Psychology, 68, 551-562. http://dx.doi.org/10.1111/j.2044-8279.1998.tb01311.x 
Sherman, J. A. (1978). Sex-related cognitive differences: an essay on theory and evidence. Springfield, Illinois: Charles C Thomas.

Stuart, C., \& Thurlow, D. (2000). Making it their own: Pre-service teachers' experiences, beliefs, and classroom practices. Journal of Teacher Education, 51(2), 113-121. http://dx.doi.org/10.1177/002248710005100205

Takacs, D. (2002). Positionality, epistemology, and social justice in the classroom. Social Justice, 29(4), 168-181.

Takacs, D. (2003). How does your positionality bias your epistemology? Thought \& Action, Summer, 27-38.

Tatum, B. D. (1997). Why are all the black kids sitting together in the cafeteria? and other conversations about race. New York : Basic Books.

Tisdell, E. J. (1999). The spiritual dimension of adult development. In M. C. Clark \& R. M. Caffarella (Eds.), An update on adult development theory (pp. 87-96). San Francisco: Jossey-Bass. http://dx.doi.org/10.1002/ace.8410

Tisdell, E. J. (2000). Spirituality and emancipatory adult education in women adult educators for social change. Adult Education Quarterly, 50(4), 308-335 http://dx.doi.org/10.1177/074171360005000404

Tisdell, E. J., Hanley, M. S., \& Taylor, E. W. (2000). Different perspectives on teaching for critical consciousness. In A. L. Wilson, \& E. R. Hayes (Eds.), Handbook of adult and continuing education. (pp. 132-146). San Francisco: Josey-Bass.

Tolliver, D., \& Tisdell, E. J. (2002). Bridging across disciplines: Understanding the connections between cultural identity, spirituality, and sociopolitical development in teaching for transformation. Paper presented at the 43rd Annual meeting of the Adult Education Research Conference. Raleigh, North Carolina. North Carolina State University.

This work is licensed under a Creative Commons Attribution 3.0 License. 